\title{
MAKING HISTORY IN BORNEO: ONG SUM PING AND HIS OTHERS DURING THE LATE YUAN AND EARLY MING DYNASTIES
}

\author{
Johannes L. Kurz* \\ Historical Studies Programme, Universiti Brunei Darussalam, \\ Tungku Link, Gadong BE1410, Brunei Darussalam \\ e-mail: jolukurz@gmail.com
}

Published online: 15 July 2018

To cite this article: Kurz, J. L. 2018. Making history in Borneo: Ong Sum Ping and his others during the late Yuan and early Ming Dynasties. International Journal of Asia Pacific Studies 14 (2): 79-104, https://doi.org/10.21315/ijaps2018.14.2.4

To link to this article: https://doi.org/10.21315/ijaps2018.14.2.4

\begin{abstract}
The Genealogy of the Sultans of Brunei (Silsilah Raja-raja Brunei) introduces an alleged Chinese ancestor whose name has been transcribed as Ong Sum Ping. Ong is said to have been related to the imperial family of China, to have ruled over Sabah in northern Borneo, and having provided his sister as spouse to one of the early sultans of Brunei. The current paper examines Ong Sum Ping and his various appearances under different names in especially Chinese texts from the twentieth century. These texts emphasise early Chinese influence on northern Borneo. Sometimes Ong Sum Ping is linked to Manarejiana, a Boni chieftain, who visited Nanjing, the capital of the Ming empire in 1408 to pay tribute and his respects to the Yongle emperor (r. 1402-1424). Through the association of the chieftain with the Ming empire, some writers suggest that Ong Sum Ping may have been an admiral of Zheng He's fleet who came to Brunei and stayed there. At the core of the paper is an examination of modern assumptions about: (1) the identity of Ong Sum Ping; (2) the existence of a Chinese province in northern Borneo; and (3) the likelihood of an appearance of the Treasure Fleet of Zheng He in Brunei in the early fifteenth century. I argue that with the extant Chinese textual sources none of these claims can be verified, and that therefore they are reflecting local oral traditions.
\end{abstract}

Keywords: Ong Sum Ping, Silsilah Raja-raja Brunei, Sabah, Huang Senping, Wang Jinghong 


\section{INTRODUCTION}

Since the inception of diplomatic relations between Brunei and the People's Republic of China in 1991, official statements emphasise long standing relations between the two countries by referring to a number of "historical" key figures of which Ong Sum Ping is one, while the others are a certain Master Pu 蒲, an alleged Chinese envoy and his tomb (dated 1264), and Manarejiana 麻那 惹加那, a presumed ruler of Brunei whose tomb is located in Nanjing (dated 1408). Ong Sum Ping is commemorated as an important figure in the early history of Brunei and thus a street in the modern capital of Brunei in Bandar Seri Begawan was named after him.

Previously scholars have worked under the premise that Ong Sum Ping was a real person. There have been several attempts over the years to shed light on the Chinese character in the genealogy of the sultans of Brunei (Silsilah raja-raja Brunei) and to read part of the legend surrounding Ong Sum Ping as a factual record. In the present article, I will show that the name "Ong Sum Ping" by no means provides a clue to the identity of the man who was attributed an eminent role in the early history of the royal house of Brunei. The Chinese characters for this person emerged in writings on the history of ethnic Chinese in Southeast Asia only in the twentieth century, and the idea of Chinese involvement in northern Borneo through a close relationship of Ong Sum Ping with either emperors of the Yuan or Ming dynasties is based on folklore that circulated in Sarawak, Mindanao and Sulu.

\section{THE BASIC CONTENTS OF THE GENEALOGY/IES}

Amin Sweeney in his study of the genealogy of the Brunei sultans distinguished between an older and a younger version of the text. ${ }^{1}$ These were held by the School of African and Oriental Studies in London (Manuscript A or MS A), and by the Royal Asiatic Society, London (Manuscript B or MS B). The oldest parts of MS A date from 1735, those of MS B from 1841, with additions from 1936. In MS A Sultan Ahmad, the brother of the alleged first Muslim ruler Sultan Muhammad, married a Chinese princess from "China Batangan," or Sabah, of whom no more is said. ${ }^{2}$

MS B, in contrast, recounts the story of two Chinese men that were sent by the emperor of China to steal a valuable gem from a dragon in Sabah. After having secured the gem, the two men quarrelled, and one of them, Ong Bong Keng, returned to China, while the second, Ong Sum Peng, remained on Borneo. ${ }^{3}$ The first Brunei ruler, Muhammad Shah gave his daughter, Puteri 
Ratna Dewi, in marriage to Ong Sum Peng who became the second sultan under the name of Sultan Ahmad. ${ }^{4}$

In MS A Sultan Ahmad is the brother of the first sultan, whereas in MS B Ong Sum Ping assumes the title Sultan Ahmad. It is clear that even though the two accepted versions of the Silsilah are differing, both of them relate the first sultan to Chinese people through his marriage to a Chinese princess in MS A, while he makes a Chinese his son-in-law in MS B. ${ }^{5}$

One possible reason for the different transcriptions of the Chinese name is its spelling in the Silsilah. Sweeney explained that the name was "not consistent" and listed "a-w-ng, a-w-a-ng" and "h-w-ng" as possible variants. ${ }^{6}$ Hence Hugh Low, for instance, referred to the two Chinese adventurers as Wang Kong and Ong Sum Ping ${ }^{7}$ whereas Sweeney presented them as Ong Bong Kong and Ong Sum Peng. Ong Sum Ping in fact is but one way to address that character, others are Ong Sum Peng, Huang Senbing, Huang Zongbing, Wang Sanping and Wang Sanpin, depending on the preference of authors dealing with the person.

\section{WEN XIONGFEI 溫雄飛 AND THE NANYANG HUAQIAO TONGSHI 南洋華僑通史 (GENERAL HISTORY OF OVERSEAS CHINESE IN THE NANYANG) (1929) ${ }^{8}$}

Wen Xiongfei was the first Chinese writer to pick up the Ong Sum Ping legend. He referred to Low's work as "original material [comprising] genealogical records of the royal house of Sulu" (yuanshi ziliao wei Sulu wangshizhi shixishu 原始資料為蘇祿王室世系書). This is clearly wrong because what he cited came from Low's translation of the Silsilah raja-raja Brunei. Similarly, Wen's reference to the Batu Tarsilah is from Low's transcription and translation of the text attached to the translation of the Silsilah raja-raja Brunei.

Though the original Malay text of the Silsilah raja-raja Brunei does not have any Chinese characters, Wen came up with the characters Huang Senping 黄森屏 for Ong Sum Ping which was but a guess for the rendering of the original characters. Wen also provided the characters Huang Gang 黃剛 for Wang Kong. He referred for his narrative to a certain Huang Zhuoru 黃卓如 who had arrived as a trader in Brunei in the early twentieth century. Huang Zhuoru befriended the then ruling sultan of Brunei (for which he gave no name). ${ }^{9}$ The sultan invited him to accompany him to a tomb, located on the ridge of a hill, about "an English mile" from the capital of Brunei (Poluoni 婆羅泥). The tomb had an inscription, but only five characters were legible 
reading “Huang Zongbing zhi mu” 黃縂兵之墓 (Tomb of Huang Zongbing). Of these Huang Zhuoru made a rubbing. How Wen arrived at Senping as the given name of the assumed occupant of the tomb is a mystery to me. Zongbing is evidently not a name, but a military title, in this case probably best rendered as commander. ${ }^{10}$

Wen thought that Huang Senping had arrived in Boni in 1375, and as Huang Senping had become either a sultan or high official in Brunei, this tomb had to be his. ${ }^{11}$

1375 was the eighth year of the reign title Hongwu of the founder of the Ming dynasty. The relevant entry in the Mingshi 明史 (Official history of the Ming, completed 1739) on Boni 浡泥 $^{12}$ does not report on a person named Wang/Huang travelling to Borneo on official business. ${ }^{13}$ It does, however, mention that in 1375 Boni was included in specific sacrifices (yuezhen haidu shanchuan zhi si 獄鎮海瀆山川之祀) that the Hongwu emperor performed personally. ${ }^{14}$ Poluoni is difficult to ascertain as the correct transcription for Brunei. Maybe the term merged the characters found in the Mingshi for Poluo 婆羅, ${ }^{15}$ as well as the second character of the term Boni 浡泥 in the same source. In any case Poluoni as a reference to Brunei is incorrect and only appears in Wen's text.

The question whether the tomb of Huang Zongbing ever existed, does not matter greatly because its location has been lost nowadays. The whole of Wen's narrative must be treated with extreme caution. He himself admitted that no Chinese records existed to support his story. ${ }^{16}$ Maybe Huang Zhuoru's story tempted him to read the name Huang Senping into the Malay original record.

Lee Khoon Choy adopted Wen's text for his popular history of Chinese in Southeast Asia. In his reading, however, Ong Sum Ping became Ong Sun Ping and $\mathrm{Ng}$ Som Ping. ${ }^{17}$ The main witness, "a prominent Chinese businessman in Brunei" is addressed as Woon Xiong Quen (corrupt for Wen Xiongfei?), and in this version of the story it is a "Cantonese trader, Huang Qhuo Qi" (Huang Zhuoru?) who discovers the tomb.

In order to fix the date of Ong/Ng's arrival in Brunei, Lee consulted Pg Karim bin Pg Haji Osman of the Brunei Museum Department who confirmed 1375 as the date of Ong Sum Ping's arrival. ${ }^{18}$ In addition, they both established that the character transcribing Ong should be Huang instead of Wang. Since they were both in agreement that Ong was Huang, they discarded the option that Ong Sum Ping may have been "Wang Qing [sic] Hong the assistant of Zheng He." 19 
Wen Xongfei also included a short account of the founding of a Chinese province controlled by the Yuan dynasty. His source was a travel writer whom he referred to as S. B. Gould and his book as "History of Sarawak." He cautioned against accepting this account as historically documented because the Yuan records made no mention of this. Instead he pointed out that it was based on local legends. The actual authors of the book with the title A History of Sarawak under Its Two White Rajahs 1839-1908 were S. Baring-Gould and C. A. Bampfylde. ${ }^{20}$ This account reverberates without being acknowledged in Hughes-Hallet's work. ${ }^{21}$

Already in 1922 Ivor Evans had had serious doubts about a Chinese origin of the word Kinabatangan and he similarly judged the alleged Chinese annexation of Sabah to be a mere legend. ${ }^{22}$ Evans called on more knowledgeable people on the subject of Dusun linguistics and based upon the replies he received (and published in his book) was confirmed in his refutation of large scale linguistic Chinese influence on the Dusun language. In 1926 Staal remarked that the "Dusun" language contained no Chinese elements, ${ }^{23}$ so the myth of a Chinese origin of some of the ethnic groups in northern Borneo should have been laid to rest by that time already. While Hughes-Hallet may be excused on accounts of the non-availability of Evans' and Staal's research to him, it is deplorable that they so far have not had any impact on the statesponsored history-writing agencies in Brunei. ${ }^{24}$

As to accounts of a Chinese administration of northern Borneo, Hugh Low reports that according to local legends in Sarawak, Brunei emerged from an original Chinese settlement. Low rightfully, in the absence of documentation as well as the very low number of Chinese present during his time, discarded this idea. Interestingly, he also remarked that no copy of the genealogy of the sultans of Brunei survived at the time of writing in $1848 .{ }^{25}$ A contemporary of Low, Gueritz noticed that tools used by the people in north Borneo were superior to those used by other groups. He reported that the origin of the tools was Chinese who "at some remote period thickly populated North Borneo." 26 He did not further specify the source of these assumptions, but most likely they reflect the same stories that other writers recorded as local traditions.

Low in his work referred to Thomas Forrest who during his expedition to New Guinea (1774-1776) also spent some in Maguindanao in May 1775. Forrest received his information through a local informant who was the brother of the reigning sultan. The document Forrest consequently cited appears to have been a family record of the Maguindanao sultans. ${ }^{27}$ The first of these was a "Serif Alli" who hailed from Mecca. The text says that "Bonsoo," who had succeeded his grandfather as ruler of Sulu, was related to the rulers of 
Borneo "which family came also from Mecca, and the head of it was brother to Serif Alli." It is noteworthy that no Chinese appear in this text, and that the relationship between Sulu and Borneo rulers is credited to a brother of the first Maguindanao sultan. The timeframe is much later than that accepted currently in Brunei, namely the late sixteenth century.

Spenser St. John referred to Forrest's account as well as to the Silsilah Raja-raja Brunei. He suggested that the genealogy "support[ed] the tradition current among the Sulus that a Chinese empire once existed in Borneo." He came to the conclusion that the assumption lacked any factual foundation. The text of the genealogy was in the possession of one of the advisers of the sultan, and judging from St. John's, was very similar to MS A. ${ }^{28}$ Ong Sum Ping did not feature in that version of the genealogy.

In 1815 John Hunt told a story he had heard from the sultan of Magindanao, though he relegated most of what local people had to say to "fables" that could hardly be trusted. In the sultan's story "the Chinese Emperor Songtiping" occupied all the ports in northern Borneo in 1375. His daughter then married "Sherif Alli" in Magindanao or thereabouts. ${ }^{29}$ Since Hunt "partly cited from memory," it is quite likely that he misrepresented the name of the "Chinese emperor." 30

It is possible that Songtiping is referring to Ong Sum Ping, but this is not very likely and cannot be demonstrated to be the case. The last Song emperor Huaizong 懷宗, personal name Zhao Bing 趙旵, is also known as Song Di Bing 宋帝旵 (r. 1272-1279), but in the context, the year 1375, the reference to him makes no sense. The only Chinese emperor active in 1375 was the Hongwu Emperor. Sherif Ali most probably refers to the legendary Sharif Ali — who in Brunei presently is considered the fourth ruler of Brunei (r. 1425-1432)—whereas in the Magindanao account he became a sultan there in the early sixteenth century. In the Brunei version Sherif Alli married the daughter of the second sultan Ahmad who had no sons in the early fourteenth century, and hence climbed the throne after the death of his father-in-law. ${ }^{31}$ Logan remarked that after Songtiping all rulers had Malay names and thus the Chinese chief had not "established a Chinese dynasty" in Brunei. ${ }^{32}$

A third version relating to Chinese settlement in north Borneo was noted in passing by Alexander Dalrymple, but he did not give the name of the Chinese person who took control of Borneo. ${ }^{33}$ Dalrymple further on in his description of Sulu, referred to a legend by the Idaan (Idahan) of North Borneo. Dalrymple explained that their story of being descendants of Chinese had "little foundation in truth." He presented the Idaan ${ }^{34}$ legend of the gem taken from a "snake" on Mt Kinabalu by a big force from China that succeeded 
in stealing it, but in the end the Chinese were overcome be the angry guardian of the treasure. ${ }^{35}$ There is no mention of specific Chinese, but the description serves as an explanation for the presence of the Chinese in North Borneo. ${ }^{36}$

Though the accounts from Sarawak, Maguindanao and Sulu are not strictly identical, they share quite a lot of similarities with the genealogy of the Brunei sultans. On the one hand, the latter is the most elaborate version because it gives names and relationships of the major actors. On the other hand, it is apparent that the Brunei version is not unique, but rests on folk lore traditions shared by people in northern Borneo and the southern Philippines.

Nicholl in 1980 came up with an even earlier date for the existence of a Chinese province in Sabah. After he had identified a geological formation recorded in an Arabic text, he concluded that this would be the west coast of Sabah conquered by the Chinese before 835 . The Chinese force sent "would have been comparatively small" and when they were left alone "melted into the local Kadazan population and disappeared." Traces of the presumed Chinese settlement were surviving in local legends, but otherwise the "Chinese colony has disappeared." 37

Why Nicholl constructed this narrative when as he himself admitted in the text it was a legend, is difficult to understand. Based solely on translations of Arabic accounts, Nicholl did not even once refer to a Chinese source that would have supported his assumptions. Prior to Nicholl, Y. L. Lee referred to the "existence of Chinese states in Borneo, or at least of Chinese rulers during that period [15th century]" and claimed that there existed "Chinese records" that reported on these states or rulers. ${ }^{38}$ Such "Chinese records" do not exist.

A few years later Nicholl modified the story of Chinese settlers in Sabah in the ninth century and replaced them with Central Asian Turks who had arrived as Chinese mercenaries there in the late thirteenth century. Nicholl explained that the Central Asian Turks still lived in Sabah in the first half of the fourteenth century. The evidence in the Yuanshi 元史 (Official history of the Yuan) notwithstanding that described a campaign against Java in 1292, ${ }^{39}$ Nicholl insisted on an entry in the work of Odoric of Pordenone to report a Borneo attack in that year. ${ }^{40} \mathrm{In}$ his imaginative version of events the mercenaries had been cut off and left behind in Sabah. In an article published one year later, he revisited his account of a Tang conquest of Sabah that he said was occupied by the Chinese from " 800 -c. $830 . " 41$ The primary Chinese official historical sources for that period, the Jiu Tang shu 舊唐書 (completed in 945) by Liu Xu 劉昫 and the Xin Tang shu 新唐書 (1060) by Ouyang Xiu 歐陽修, contain no information about Chinese soldiers or colonists dispatched to Borneo by the imperial court. Given the lack of evidence for any of Nicholl's claims, we can safely discard them and confine them to the realm of fiction. 


\section{HUANG JINGCHU 黃競初 AND THE HUAQIAO MINGREN GUSHILU 華僑名人故事錄 (RECORD OF STORIES ABOUT WELL- KNOWN OVERSEAS CHINESE PEOPLE) (1940)}

In Huang Jingchu's account of Chinese immigrants to north Borneo Zhuo Mou 卓謀, a Hakka and erstwhile follower of the Song loyalist Wen Tianxiang 文天祥 (1236-1283) took centre stage. Zhuo managed to escape capture by the victorious Mongols in 1279 and moved to Borneo where he established a state in the north of the island. ${ }^{42}$ The fictional episode has been included in Lo Jungpang's posthumously published book on the Chinese navy from the twelfth to the fourteenth centuries. ${ }^{43}$ Huang ascertained the veracity of the incredible story by providing his personal eye-witness account: "When I travelled to the north coast of Borneo, I often came across ruins of fortifications in Chinese style, and I learnt that these were remnants of the time of Zhuo's rule."

In the preceding paragraph, he had described a conflict between the local people and the Chinese and how Zhuo had defeated indigenous resistance by means of building fortresses. Huang Jingchu did not divulge the name of the guide who told him of the provenance of the alleged Chinese ruins nor did he provide information on their exact location. Huang perhaps learnt about Zhuo only when he was in Borneo and therefore recorded a legend told by local people.

Huang Jingchu furthermore talked about a person addressed as Poluo wang 婆羅王 (king of Borneo). ${ }^{44}$ From the contents it is possible to identify the Poluo 婆羅/Wenlai 汶萊 entry in the Mingshi as the main source for this anecdote. Geoff Wade has demonstrated that this Mingshi entry does not talk about Brunei ${ }^{45}$ The only new element in Huang Jingchu's narrative is that the anonymous man from Fujian in the Mingshi entry is given a vague royal title “mou jia” 某甲 (“something jia"). This title is not mentioned in the original Mingshi text. The composite character of the text highlighted by Wade is evident in the following paragraph (quoting Wade's translation): "During the Wan-li reign (1573-1619), a person from Fujian ruled here as king. Some say that Zheng He went as an envoy to Po-luo and was followed by people from Fujian." The reference to a Chinese ruler in the Wanli period derives from the entry on Wenlai in the Dong Xi yang kao 東西洋考 that dates to 1617, hence the very late Wanli reign. The Mingshi compilers in the first half of the eighteenth century copied the text from the Dong Xi yang kao. The Dong Xi yang kao explained that "the present king" had come with Zheng He to Wenlai and had settled there. The "present king" could not have been the one ruling in 1617 , because he would have easily far older than two hundred years. 
We may understand this passage to mean that since the Zheng He voyages between 1406-1433 local rulers had been Chinese. Interestingly, authors intent on demonstrating early China-Brunei relations like to point to a visit by Zheng He or his fleet. ${ }^{46}$ It is obvious that this visit has been derived either from the Dong Xi yang kao entry ${ }^{47}$ or its consequent inclusion in the Mingshi text. The problem is that by accepting the Poluo/Wenlai text in the Mingshi, one confirms Chinese rulers in Brunei since the early fifteenth century who had continued to rule until the early seventeenth century. Authors frequently refer to the Mingshi entry on Boni as an early account of the state, but this entry does not mention Zheng He once. To cut him from the Poluo/Wenlai entry and paste him into the Boni account that allegedly does describe an early Brunei, is inaccurate and wrong. Unless of course, one admits that the royal house of "Brunei" for at least two hundred years was Chinese. In that case, however, the Mingshi entry on Boni has to be discarded as a description of an early Brunei.

\section{HUANG YAO 黃堯 AND THE MA XING HUAREN ZHI 馬星華人志 (HISTORY OF THE CHINESE IN MALAYSIA AND SINGAPORE) (1967)}

In an article on the history of North Borneo, Pan Xianreng 潘先仍 wrote: "Records report that Ahmad, the younger brother of Sultan Mohammad, married the daughter of Wang Sanping 王三平 (Ong Sun Ping), a Chinese commander (zhongguo zongbing 中国总兵), and later Ahmad ascended the throne as the second sultan." Pan in an accompanying footnote remarked on the differing versions of the royal genealogy (wangshi shixi shu 王室世系 书). ${ }^{48}$

Huang Yao, author of the Ma Xing huaren zhi 馬星華人志, ${ }^{49}$ may have had access to Pan's article. Huang's book is not strictly a historical text. In the chapter on Sabah (Shaba 沙芭), Huang turned to the genealogy of the Brunei royal family and introduced Wang Kong and "Wang Sum Ping" whom he represented with the characters 王剛 (Wang Gang) and 王三品 (Wang Sanpin), respectively.

Huang cited the relevant entry from Wen Xiongfei's book, but rendered Huang Senping as Huang Shengping 黃昇平 and declared that Huang and Wang possessed an identical pronunciation. As for the variant degrees of familial relationship he made the valid point that the exact relationships did not matter, but that Chinese were featuring prominently in the early royal family of Brunei. As to the reason why Wang Sanpin was in Sabah he explained: 
Wang Sanpin arrived in North Borneo (Bei Poluozhou 北婆儸洲) in the twenty-ninth year of the Zhiyuan era of the Yuan dynasty, that is the year 1292 AD. Since emperor Shizu of the Yuan (r. 1260-1294) had dispatched troops to attack faraway places, he once established a provisional province (xing sheng 行省) in North Borneo. In addition, in order to exercise power over the Sulu archipelago, he dispatched a commander-in-chief (zongdu 總督) whose official position may well have been that of zongbing 縂兵. His name was Ong Sum-ping for which the transliteration is Huang Shengping; or Wang Sum-ping for which the transliteration is Wang Sanpin. The old tomb of Huang Zongbing is definitely his, and if his family name was Ong, in that case his family name was Huang without a doubt. ${ }^{50}$

Xingsheng as an administrative term refers to a branch secretariat. Hucker explains that it may also be encountered as a reference to an overseer in the Yuan dynasty. ${ }^{51}$ I chose the present translation in the context of the very short existence of this alleged part of the Chinese empire. Zongdu is used anachronistically by Huang Yao for this is a title used in the Ming; in the Qing the title identified a Governor-general, and maybe that is what Huang had in mind.$^{52}$ Huang claimed that the genealogies of the Sulu sultans (Sulu wangshi jiapu 蘇祿王室家譜) also recorded Wang Sanpin or Huang Shengping. ${ }^{53}$ What he cited in Chinese translation is more or less a text similar to the MS B of the Silsilah Raja-raja Brunei, so I suspect that he adopted the Sulu genealogy from Wen Xiongfei. The existing genealogies of the Sulu sultans do not report on a prominent Chinese man. Rita Tuban in her study of the genealogy of Sulu sultans ("Sulu salsilah") used a version dating from the early twentieth century. Chinese do not figure in that text. ${ }^{54}$ Neither do the tarsilahs of Sulu sultans that Cesar Adib Majul scrutinised mention any Chinese involvement. ${ }^{55}$ According to Majul the genealogies report that the earliest Muslim preachers arrived in the company of Chinese traders who are not further identified by name. ${ }^{56}$ 


\title{
CHEN LIEFU 陳烈甫 AND THE DONGNANYA HUAQIAO, HUAREN, HUAYI 東南亞華僑華人華裔 (ETHNIC CHINESE AND THEIR DESCENDANTS IN SOUTHEAST ASIA) (1979)
}

Chen Liefu told the following story:

\begin{abstract}
According to Western historical works, the Yuan dynasty of China controlled the Southern Ocean, and emperor Shizu had dispatched troops on a distant journey to Brunei (1292, the 29th year of the Zhiyuan era). He sent an official to take charge of them whose name was Wang Sanpin 王三品 and consequently Chinese went there in large numbers. The sultan of that place (Sultan Mohamed) gave his only daughter in marriage to Wang Sanpin, and their son inherited the throne as sultan (Sultan Akhmed). Therefore, the royal family of Brunei has close blood ties to China. The highest mountain in Sabah is called the Mountain of the Chinese Widow 中國寡婦山 (Zhongguo guafu shan) (also called Sacred Mountain), and the name of the longest river there is China River 中國河 (Zhongguo he), and this is also sufficient as proof that China and that place had early relations. ${ }^{57}$
\end{abstract}

This text is a good example how misconceptions are being perpetuated. The "Western history books" referred to is the Baring-Gould and Bampfylde text that Wen Xiongfei had consulted in 1929. From that text Chen copied the fabricated idea that Kublai Khan sent troops to Borneo in 1292, as well as the Chinese origin for the designations of both Mt. Kinabalu and the Kinabatangan River. ${ }^{58}$ The name of the official, Wang Sanpin, Chen added from Huang Yao's text from 1967. Chen did not once refer to original first-hand sources to underline the veracity of his narrative.

\section{WANG JINGHONG 王景弘 (ALSO宏) (?-1434) IN THE HISTORY OF BRUNEI}

Nicholl complicated things in a text that has never been published, but nevertheless has circulated as a manuscript in Brunei. Though Nicholl accepted that Zheng He never set foot on Borneo, in order to explain the origins of Ong Sum Ping he invented another seafarer he addressed as Wong Soon Peng, ${ }^{59}$ but without Chinese characters. ${ }^{60}$

Nicholl may or may not have been influenced by Harrison who had earlier suggested a connection between Zheng He's voyages and the appearance of Ong Sum Ping in the "chronicles" of Brunei. ${ }^{61}$ Nicholl certainly has to be 
credited for putting Brunei on the historical map, but is similarly notorious for engineering quite a lot of details that cannot be verified as facts. The above is one of those instances. Sura Wangsa is his rendition of Xiawang 遐旺 who was the son of the Boni chieftain Manarejiana, who visited Nanjing in $1408 .^{62}$ "Admiral Wong Soon Peng" must be a figment of Nicholl's imagination, as this person is not listed in the Chinese sources. Is it possible that Nicholl engaged the services of a Cantonese speaker to transcribe the characters for "Huang Zongbing"? The transcription of the family name and the title would explain why he thought this person to have been an admiral. Assuming that Nicholl understood this admiral to belong to the group of eunuchs having been sent out by the Yongle emperor, it is near impossible to believe that he would have married a Bruneian princess. ${ }^{63}$ There is no reason to accept Nicholl's statement about this admiral's exploits, because they did not exist. Nicholl had no clue as to the transformation of his Wong Soon Peng into Ong Sum Ping and hence did not explain it.

$\mathrm{Wu}$ Zongyu also ventured into guessing that one detachment of Zheng He's fleet led by Wang Jinghong ${ }^{64}$ visited Borneo. He suggested that Wang Jinghong as a commander had the fitting title zongbing and henceforth would have been "Wang Zhong [sic] Bing."

As to Wen Xiongfei's description of Huang Zongbing's tomb he declared that it was difficult to decide, whether it belonged to an actual person or if it was merely a symbolic tomb. He did not question the existence of the tomb per se. ${ }^{65}$

In an attempt to reconcile the Malay records as presented by Low and Sweeney with the Chinese records for which he consulted Groeneveldt's translation of the Mingshi entry on Boni, ${ }^{66}$ Jamil Al-Sufri discussed the idea that Manarejiana, the Boni chieftain in 1408, had been Ong Sum Ping. ${ }^{67} \mathrm{He}$ discarded that idea consequently, but why he brought it up in the first place, must remain a mystery. Paradoxically Abdul Latif in 1996 re-visited the Manarejiana/Ong Sum Ping complex. He suggested that "Ong Sum Peng's [sic] son (or another relative of Chinese origin) was the most likely candidate for Ma-na-re-ka-na." 68 Because of his assumed Chinese heritage he "could not seek a better place than China to endorse his legitimacy, and his visit to China can be seen as an attempt to consolidate his rule through recognition by emperor Yong-lo [...]." ${ }^{\circ 9}$

The Chinese sources do not address the ruler of Boni as Chinese. If we disregard the wrong dedication of the particular Mingshi entry on Poluo/ Wenlai, the man from Fujian who established a royal family was not Ong Sum Ping either. 
It should be noted though, that in a text of 1371 describing a mission from the Ming court to Borneo (Boni) in 1370, a close adviser of the Boni chieftain Mahemosha 馬合謨沙 appears to have been Chinese judging from his name Wang Zongshu 王宗恕. ${ }^{70}$ Nothing further is known about this man. Given that scholars lacking competence in Chinese generally neglect transcriptions for the alleged Ong Sum Ping, it is not surprising no one has ventured to identify Wang Zongshu with Ong Sum Ping. Being Chinese, serving the ruler, and being there at the right time in the 1370s, he certainly would figure well as a prime suspect for the character of Ong Sum Ping.

Liu Youping 刘佑平, author of a volume dealing with the history of the Huang surname in China, gives yet another narrative that reads as follows: ${ }^{71}$

At around the start of the fourteenth century, that is the later years of the Yuan dynasty, Huang Senping (Wong Chun Ping), an unsuccessful official of the Yuan dynasty, was appointed envoy for Poluo 婆罗国 (modern Brunei). After his arrival in Poluo, old gentleman Huang was reluctant to leave and did not return, so he settled in Poluo to become a prominent Chinese. Later, Huang Senping because of his unique talent to win the affection of the local ethnic Chinese, became the leader of the Chinese in Brunei. Even later, Huang Senping became the ruler of Poluo, serving as governor of Kinabatangan, commander and sultan which means that in effect he became king... After Huang Senping had passed, he was buried in Brunei. His sons and grand-children remained there and their descendants became very well-known. According to the historical records, Huang Senping had a daughter who was given in marriage to Akhmed, the second sultan of Boni (Bruni, modern Brunei), in the eight year of the Hongwu era of the Ming (1375). After Akhmed's death, Huang Senping's daughter succeeded to the throne and became king of Brunei. From then on, the succession of Brunei kings was passed on through the female lineage. After the death of the née Huang, the queen of Boni, the throne passed to the daughter that had been born to her and Ahmad. This second female king of Boni married a chieftain Ali (Sharif Ali), an Arab who had come to Brunei. Until this century more than twenty Brunei kings have succeeded each other, and they are all direct descendants of the female offspring of Huang Senping. Therefore, the royal family of Brunei throughout history has revered Huang Senping as its ancestor and until today there exists a so-called Huang Zongbing tomb in Brunei which has always received ceremonies of repair by the royal family of Brunei. 
The commentary by the creator of the Brunei section on Huang family website, Huang Baoxin 黄宝新, is naturally very critical of Liu Youping's narrative because Huang wants to claim Ong Sum Ping for his own family. If one accepts Liu Youping's account and the present royal genealogy, then indeed the sultans of Brunei have much to thank Ong Sum Ping's sister and her daughter for. The Mingshi entry on Boni remarks that when the Boni king died during the Wanli period (1573-1619), he left no successor. A struggle for the throne ensued that cost most of the contenders their lives and as a consequence the daughter of the late king ascended the throne. She had a Chinese advisor by the name of Zhang 張 who hailed from Zhangzhou 漳州 in Fujian. When he was accused of treachery by his own daughter, he committed suicide, but upon an examination of the case it was found that his daughter was mentally instable and had made up her father's treason. ${ }^{72}$ However, it appears that this piece of information like the remainder of the entry is not dealing with Boni, but rather with Pattani (Dani 大泥). ${ }^{73}$ Although Brunei historians are generally open to include pieces of information, they so far have not inserted this queen into the royal genealogy. The fact that the queen was a Patani ruler may be one reason for her rejection as a Brunei ruler. Another reason could be that her acceptance as a ruler would undermine the royal genealogy of male Muslim rulers that is otherwise and to a large degree based on the same Mingshi entry.

\section{MODERN BRUNEI WRITERS}

Jamil Al-Sufri presented a highly interesting rendition of the story which was based on a number of components that had not been constructed in this way before. $^{74}$

For the date of Ong's arrival in Brunei, Jamil Al-Sufri referred to Wen Xiongfei. The second piece of information concerning the marriage between Ong's younger sister and Brunei's second sultan, he explained further in a footnote: "It is not known who made him [Ong] chief in Kinabatangan. Most probably being of Royal Chinese Blood [sic], he became Chief of the Chinese settlers in Kinabatangan." 75

Local scholars usually without further linguistic evidence repeat the assumption that the names Kinabatangan and Mount Kinabalu have Chinese origins. ${ }^{76}$ In that vein Jamil Al-Sufri in the footnote to the last sentence promoted Ong from a mere chief to a "Chinese King from Chinabatangan." 77 He claimed that the story of Ong Sum Ping and his brother "Ong Kang" was told in a similar fashion in the "Tarsilah Raja-Raja Suluk" (Genealogy of the 
Sultans of Sulu(?)), and referred the reader again to Wen Xiongfei. ${ }^{78}$ It appears that Jamil had not understood Wen's Sulu genealogy to be Low's essay on the genealogy of the Brunei sultans. The family relationship between Ong Sum Ping and Ong Kang is not attested to by the Silsilah Raja-raja Brunei.

Calculating the respective ages of Ong Sum Ping and Manarejiana in 1408 (53 and 28), Jamil Al-Sufri concluded that the two were two different persons. The name of the princess he derived from the reading of another version of the genealogy of the Brunei sultans which does very clearly not relate to the two established MS. The part that interests us here reads in Jamil's translation: ${ }^{79}$ “... The third was a daughter named Puteri Mengindera Dewi who was married to a Chinese King." Jamil Al-Sufri assumed that the Ong Sum Ping from MS B would have been that "Chinese King" as no personal name is given. Ampuan Haji Brahim explained that the correct name of the lady, Puteri Ratna Dewi, derived from the genealogy inscribed on stone (Batu Tarsilah). ${ }^{80}$ Both Jamil and Ampuan Haji Brahim noticed the differences in the status of Ong Sum Ping in the versions of the genealogy, but did not go further than stating them. According to Ampuan Haji Brahim Ong Sum Ping had a sister "Princess Kinabatangan" who "married Pengiran Patih Berbai (later Sultan Ahmad)." In this instance, the family of Ong Sum Ping is increased in size by a sister with a title. The Silsilah Raja-raja Brunei does not specify that relationship. The title of the princess is a short title for the entry in MS A of the Silsilah Rajaraja Brunei which talks of a Chinese princess from Kinabatangan. According to Jamil this princess was not only from China, but she was also a sister of the emperor of China. ${ }^{81}$ As the Boni chieftain Mahemosha in the Mingshi is assumed to have been Brunei's first sultan Mohammed Shah (r. 1368-1402), ${ }^{82}$ Ong Sum Ping in that reading would be a brother of the Hongwu emperor (r. 1368-1398) of the Ming dynasty. That is rather impossible.

Since Ong is either referring to the family names Huang 黃 or Wang 王, Ong could not have been related to the Ming founder (r. 1368-1398) whose family name was Zhu 朱, nor to any of the rulers of the Mongol Yuan dynasty (1279-1368) either. The family name of the Mongol rulers was Borjigin (Chinese transcription: 孛兒只斤). If indeed Ong had been related to either the Yuan emperor (in 1292) or the Ming emperor (in 1375), it would have been through a female relative. Therefore, we need to look at the consorts of both Kublai Khan and the Hongwu Emperor with the family names Huang and Wang. None of the consorts of Kublai Khan fulfill the required criteria as they were all non-Han females. ${ }^{83}$ None of the four consorts of the Hongwu emperor had the surname Huang or Wang. ${ }^{84}$ The possibility that Ong Sum Ping was related through a consort of lesser rank not recorded in the official histories of 
the Yuan and Ming may exist, but is minimal. Hence the whole construction of family ties between Ong Sum Ping and the Chinese imperial family lacks any solid evidential basis.

Despite these apparent inconsistencies the Brunei History Centre published a genealogy that reported a marriage between Puteri Ratna Dewi with Ong Sum Ping, "a relative of the Chinese emperor." ${ }^{85}$ Jamil Al-Sufri explains that Ong's wedding occurred in 1390 and refers to Chinese sources. The only Chinese source found in his text for this part of early Brunei history is Wen Xiongfei's text that does not provide a date for the alleged wedding. ${ }^{86}$

The Boxer Codex mentions a Chinese connection between the first ruler named Sultan Yuso of "Borney" through marriage to a Chinese princess. ${ }^{87}$ The transmission history of the Boxer Codex, compiled probably at the end of the sixteenth century in Manila, is somewhat obscure, but specialists assume that it is a genuine article. The passage here would constitute a local and most likely oral tradition. ${ }^{88}$ For Jamil Al-Sufri sultan Yuso was an Arab from Aden and a relative of the alleged third Brunei sultan Sharif Ali. This sultan Yuso furthermore visited China from Aden with a fleet upon an invitation that Zheng He had submitted to him in $1405 .{ }^{89}$ Zheng He previously had also visited Brunei according to Jamil Al-Sufri. We can safely discard these allegations, because Zheng He visited Aden only on his fifth voyage from 1417-1419 and never set foot in Brunei.

Close attention must be paid to the identification of Manarejiana with sultan Abdul Majid Hasan. The Mingshi says that little Xiawang who was about four years old succeeded his father as ruler after the latter's death in 1408 and was also accepted as such by the Chinese. Xiawang is not listed in the officially accepted succession of Brunei sultans.

Local writers understand the relevant Mingshi entry as dealing with a Muslim sultan from Brunei, ${ }^{90}$ under the assumption that Boni referred to Brunei, and not to Borneo in general. ${ }^{91}$ Abdul Majid Hasan is a relative newcomer in the royal Brunei genealogy, as he was only inserted in the late twentieth century into the succession of Brunei sultans..$^{92}$ The reason for this ambiguous treatment was that his name did not appear in the Genealogical Tablet (Batu Tarsilah) from 1807.93

There was no real need to include Manarejiana as either the second or the third sultan, other than here was a chieftain from Borneo recorded in Chinese sources, whereas the other early sultans were legendary. Nicholl suggested that Mahemosha, the Boni chieftain's name in the Mingshi, was a transcription for Maha Moksha and thus ascribed a Buddhist background to the ruler whom he firmly planted in Brunei. To Nicholl, Manarejiana or 
Maharaja Karna was either "the grandson or nephew" of Maha Moksha, and hence a non-Muslim. ${ }^{94}$ Nicholl derived the reading "Maharaja Karna" from a list of Brunei titles contained in Donald E. Brown's monograph.$^{95}$ The question remains whether the use of Malay royalty titles listed in a twentieth century work to identify - most likely - indigenous names in Chinese texts from the fourteenth and seventeenth centuries is permissible. The modern title Maharaja Karna is not of high-rank, and Nicholl never submitted an explanation why in the early fifteenth century it would denote the personal name of a ruler. The relevant Chinese sources from the early Ming dynasty do not link Mahemosha and Manarejiana, nor do they report on the religious affiliations of the two men.

\section{CONCLUSION}

The appearance of Ong Sum Ping in the genealogy of the Brunei sultans most likely reflects oral local lore concerning the presence of Chinese who not necessarily would have made it to Boni in the late fourteenth or early fifteenth century. It is more viable that Chinese immigrated at a time when Borneo was better known as a place to trade in. ${ }^{96}$ The characters of Ong Sum Ping and Ong Kong/Wang Kong in the royal genealogies are fictional, so the search for Ong Sum Ping is futile. It does not make much sense to link the genealogy of Brunei sultans from the nineteenth century to the Chinese records of Boni from the early Song dynasty to the early Ming dynasty.

No textual nor archaeological evidence exists for Chinese presence in the form of a colony or province in north Borneo in the late Tang or the late Yuan dynasties. This does not preclude the possibility of Chinese settlers in the region, but it shows that there were no official efforts to colonise parts or all of north Borneo during the relevant periods. The appearance of Ong Sum Ping in the genealogy is rather late and is reported for the first time only in Low's translation of the Silsilah Raja-raja Brunei. St. John in 1863 had no knowledge of Ong Sum Ping though he had consulted the then prevalent version of the genealogy.

Stories about an alleged Chinese province and a Chinese leader in Sabah circulating in a large area comprising northern Borneo with Sarawak and Sabah, as well as the southern Philippines, in Maguindanao and Sulu certainly made an impact on the compilation process of the more recent version of the genealogy. None of these traditions are grounded in historical reality nor are they reflected in the existing official and unofficial Chinese histories 
from Yuan, Ming and Qing times. Indeed, only in the early twentieth century have Chinese authors become interested in the idea of Chinese presence in northern Borneo. These authors, like Wen Xiongfei for instance, intended to demonstrate a long history of Chinese settlement in northern Borneo. Some of these works drew on the legends reported in Western works. The Ong Sum Ping complex of narratives make the northern parts of Borneo home to permanent Chinese settlers since the fourteenth century. With the acceptance of the local legends Chinese were made part of the early groups of immigrants and were established as age-old dwellers, instead of newly-arrived sojourners.

\section{NOTES}

* Johannes L. Kurz (PhD in Classical Chinese Studies, University of Heidelberg, 1993), after graduating worked as an assistant professor in the Institute of Oriental Studies at the University of Kiel, Germany. In 1998 he joined the History Department at Universiti Brunei Darussalam. He specialises in the history of China from the tenth to the eleventh centuries. He has published two books, the latest being China's Southern Tang Dynasty 937-976 (Routledge, 2011) and a number of articles on this topic. In addition, he is interested in the relations between China and Southeast Asia and their descriptions in Chinese sources. A recent article on one of many aspects of this field has been published as "Pre-modern Chinese Sources in the National History of Brunei: The Case of Poli," in Bijdragen tot de Taal-, Land- en Volkenkunde 169 (2013): 213-243. Another area of interest is the depiction of the South China Sea in pre-modern Chinese sources and their interpretation by historians in China as well as in the West.

1 Sweeney, P. L. A., "Silsilah raja-raja Berunai," Journal of the Malaysian Branch of the Royal Asiatic Society (JMBRAS) Vol. 41, No. 2 (1968): 1-4.

2 Ibid, 11. The transcriptions for the names are Sweeney's. When not citing the transcriptions of other authors, I am addressing the person in question as Ong Sum Ping.

3 Ibid, 52.

4 Ibid, 53-54.

5 This is the version favoured by Denys Lombard and Henri Chambert-Loir who address the second sultan as "Sultan Ahmad (d'origine chinoise)." See their "Guide Archipel VIII: Le Sultanat de Brunei Darussalam," Archipel Vol. 39 (1990): 22. Donald E. Brown summarised the problems inherent in the Brunei royal genealogies in his Brunei: The structure and history of a Bornean Malay Sultanate (Brunei: Brunei Museum, 1970), 136. A similar summary is found in Graham Saunders, A history of Brunei, 2nd ed. (Abingdon: Routledge, 2002), 40 and 42.

6 Sweeney, "Silsilah," 52.

7 Low, H., "Selesilah (book of the descent) of the rajas of Brunei," JMBRAS Vol. 5 (1880): 2.

8 Wen, X., Nanyang huaqiao tongshi 南洋華僑通史 (Shanghai: Dongfang yinshuguan, 1929). 
9 The two relevant sultans ruling in the early twentieth century were Hashim Jalilul Alam Aqamaddin (r. 1185-1906) and Muhammad Jamalul Alam II (r. 1906-1924).

10 Regional commander is Hucker's translation of the term zongbing guan 總兵官 for this title in the Ming. See Charles O. Hucker, A dictionary of official titles in Imperial China (Stanford: Stanford University Press, 1985), entry 7146, 533.

11 Wen, Nanyang huaqiao tongshi, 64-66.

12 Mingshi, compiled by Zhang Tingyu 張廷玉 et al. (Beijing: Zhonghua shuju, 1974), 325.8411-8415.

13 See Zhang, T. 張廷玉 et al., Mingshi 明史 (Beijing: Zhonghua shuju, 1974), 2.302.31 .

14 See Kurz, J. L., "Boni in Chinese sources: Translations of relevant texts from the Song to the Qing Dynasties," Nalanda-Sriwijaya Centre Working Paper 4 (July 2011), 35.

15 Mingshi, 323.8378.

16 Note that Wang Qing 王青 used Wen Xiongfei's text in his article on the historical relations between China and Brunei, but did not acknowledge Wen as his source of information. See his "Lidai Zhongguo yu Wenlai de youhao jiaowang” 历代中国与文 莱的友好交往, Dongnanya Vol. 2 (1998): 53-54. Wang referred to the tomb as Wang zongbing (zhi) mu 王总兵(之)墓 and addressed Wang as Wang Sanpin 王三品. Wang Qing probably copied this name from Huang Yao's work (see below) whom he similarly did not acknowledge.

17 Lee, K. C., Golden Dragon and Purple Phoenix: The Chinese and their multi-ethnic descendants in Southeast Asia (Singapore: World Scientific Publishing, 2013), 533 and 530 respectively. The transcription "Ong Sun Ping" is also found in Lin Yuanhui's 林远辉 and Zhang Yinglong's 张应龙 monograph on the history of ethnic Chinese in Singapore and Malaysia. They are, however, cautious to provide any Chinese characters, and merely explain that "some scholars" (youde xuezhe 有的学者) pointed out that the Huang Zongbing of the tomb was "Ong Sun Ping." See their Xinjiapo Malaixiya huaqiaoshi 新加坡马来西亚华侨史 (Guangzhou: Guangdong gaodeng jiaoyu chubanshe, 1991), 67. Their main source for Ong Sun Ping is Wen Xiongfei. Lee refers to "The Philippine islands written by H. Clarke Company in 1903" as the source for another version of the Ong Sum Ping story, but he does not divulge where exactly that information is given. See Lee, Golden dragon, 530. The correct title of the immense work in fifty-five volumes is The Philippine islands 1493-1898: Explorations by early navigators, descriptions of the islands and their peoples, their history and records of the Catholic missions, showing the political, economic, commercial and religious conditions of those islands from their earliest relations with European nations to the close of the nineteenth century. Emma Helen Blair and James Alexander translated the original documents from various languages, and edited and annotated all the texts. The text was published from 1903 to 1911 by the Arthur H. Clarke Company in Cleveland Ohio. I have in vain searched for a mention on Ong Sum Ping in the online version of the complete text, but could not find any reference to him. The online (searchable) version can be accessed for free at http://philhist.pbworks.com/w/ page/16367055/ThePhilippineIslands (accessed 6 March 2017). 
20 The relevant paragraph reads: "When Genghis Khan conquered China, and founded his mighty Mogul Empire (1206-1227), it is possible that he extended his rule over Borneo, where Chinese had already settled. Kublai Khan is said to have invaded Borneo with a large force in 1292; and that a Chinese province was subsequently established in northern Borneo, in which the Sulu Islands were included, is evidenced by Bruni and Sulu traditions." See S. Baring-Gould and C. A. Bampfylde, A history of Sarawak under its two White Rajahs 1839-1908 (London: Henry Sotheran, 1909), 36-37. This paragraph does not inspire confidence in the historical knowledge of the writers, since Genghis Khan never conquered China and did not found the Moghul empire. These tasks were left to his sons and grandsons.

21 "Kublai Khan, the Mongol Conqueror, is known to have sent an expedition from China to the eastern archipelago in 1292. And it is more than probable that this was the origin of the Chinese colony in northern Borneo which is commemorated in the nomenclature of the Kinabatangan river and the mountain Kinabalu and which according to tradition provided Brunei with a ruler." See Hughes-Hallett, H. R., "A sketch of the history of Brunei," JMBRAS Vol. 18, No. 2 (1940): 24.

22 Ivor Evans, Among primitive peoples in Borneo: A description of the habits and customs of the piratical head-hunters of North Borneo, with an account of interesting objects of prehistoric antiquity discovered in the island (London: Seeley, 1922), 274-290. These pages form the highly informative chapter entitled "The Chinese in Borneo."

23 J. Staal, "The Dusuns of north Borneo: Their social life (continued)," Anthropos Vol. 21, No. 5-6 (1926): 940. For more surveys of indigenous languages in north Borneo see G. N. Appell, "The Dusun languages of northern Borneo: The Rungus Dusun and related problems," Oceanic Linguistics Vol. 7, No. 1 (1968): 1-15, and Robert Blust, "The greater north Borneo hypothesis," Oceanic Linguistics Vol. 49, No.1 (2010): 44-118.

24 One example of a non-Bruneian author to disregard linguistic evidence is Wan Kong Ann who as late as 2013 claimed that "In the local Malay language, Kina (Cina) means 'Chinese,' batangan means 'river,' and balu means 'widow." See "Examining the connection between ancient China and Borneo through Santubong archaeological sites," Sino-Platonic Papers 236 (2013): 7. Wan ignored the existence of indigenous languages and their references to geological and topographical features of their lands for the sake of the Malay language. The Brunei History Centre in its publications has stuck to the idea of a Chinese province in Sabah and disregarded the etymological evidence pointing to the contrary. This is even more regrettable in light of Robert Nicholl's article on early Brunei history in which he made this information available. See his "Some problems of Brunei chronology," Journal of Southeast Asian Studies Vol. 20, No. 2 (1989): 181182, fn. 57. The example goes to show that research published outside Brunei by nonBruneians is easily ignored by officials employed by the Bruneian government.

Low, H., Sarawak: Its inhabitants and productions, being notes during a residence in that country with His Excellency Mr. Brooke (London: Richard Bentley, 1848), 94-96.

26 Gueritz, E. P., "British north Borneo," JMBRAS Vol. 14 (1884): 332 and 334.

27 Forrest, T., A voyage to New Guinea and the Moluccas from Balambangan including an account of Magindano, Sooloo, and other islands (Dublin, 1779), 215.

28 See his Life in the forests in the Far East, vol. 2 (London: Smith, Elder and Co., 1863), 832. 
29 Hunt, J., "Some particulars relative to Sulo in the Archipelago of Felicia, collected partly from a parcel of shattered and torn memoranda, and partly cited from memory," in Malayan miscellanies, vol. 1 (Bencoolen: Sumatran Mission Press, 1820), 4-5. The report is dated to 17 December, 1815.

30 Charles Wilkes said he heard the same or very similar story, but it also possible that he merely quoted Hunt's text. See Charles Wilkes, Narrative of the United States exploring expedition during the years 1838, 1839, 1840, 1841, 1842, vol. 5 (Philadelphia: Lea and Blanchard, 1849), 349.

31 Sweeney, "Silsilah," 11 for MS A, and 54 for MS B.

32 Logan, J. R., "Notices of Chinese intercourse with Borneo proper prior to the establishment of Singapore in 1819," Journal of the Indian Archipelago and Eastern Asia Vol. 2 (1848): 611.

33 Dalrymple, A., "Essay towards an account of Sooloo," in Oriental repertory (London, 1791-1797), 540.

34 According to Appell, Idaan was the term with which Malays living in the coastal area of north Borneo addressed the non-Muslim indigenous people. See Appell, "Dusun languages," 1.

35 Dalrymple, "Sooloo," 558-559. Dalrymple remarks further that the first Chinese traders arrived in Sooloo during "Sahabodin's reign." See Dalrymple, "Sooloo," 577. This appears rather late, but may explain the absence of Chinese in the surviving genealogical texts from Sulu. Sahabodin most likely refers to the sultan addressed as Shahabud-Din (r. 1685-1710). Incidentally John Crawfurd believed that trade between Borneo and China was of "considerable antiquity," but that no written sources attested to the trade. He inferred the antiquity of the trade from the quantity of Chinese objects in use in Borneo as well as the adoption of Chinese weights and measures. See Crawfurd, J., $A$ descriptive dictionary of the Indian islands and adjacent countries (London: Bradbury and Evans, 1856), 62.

36 The legend about the snake and the consequent Chinese occupation of north Borneo is retold in Owen Rutter, British north Borneo: An account of its history, resources, and native tribes (London: Constable and Co., 1922), 85-86.

37 Nicholl, "Brunei rediscovered: A survey of early times," Brunei Museum Journal Vol. 4, No. 4 (1980): 224. This article was published consequently under the same title in Journal of Southeast Asian Studies Vol. 14, No. 1 (1983): 32-45.

38 Lee, Y. L., "The Chinese in Sabah (North Borneo) (Die Chinesen in Sabah (Nordborneo))," Erdkunde Vol. 19, No. 4 (1965): 307.

39 Nicholl, "Brunei and Camphor," Brunei Museum Journal Vol. 7, No. 1 (1989): 14. The entry in the official history of the Yuan is found in Song Lian 宋濂 et al., Yuanshi (Beijing: Zhonghua shuju, 2005), 210.4665.

40 Nicholl, "Brunei and Camphor," Brunei Museum Journal Vol. 7, No. 1 (1989): 16. Nicholl explained that there was one "island of Clouds, Storms and Rain" that he said was the common Arabic reference to "the west coast of Sabah." This is not what the original French text has which describes three islands. See Gabriel Ferrand, Relations de voyages et textes géographiques arabes, persans et turks relatifs à l'Extreme-Orient du 8e au 18e siècles; traduits, revus et annotés, vol. 2 (Paris: Ernest Leroux, 1913), 375. Similarly, the reading of Odoric's text as a description of a conflict between the Yuan and Borneo is incorrect, since Odoric referred distinctly to the Yuan attack against Java 
in 1292 and did not even with one word refer to Borneo. Cf. the translation of Odoric's text "The travels of Friar Odoric of Pordenone (1316-1330)," in Henry Yule (transl.), Cathay and the way thither, vol. 4 (London: The Hakluyt Society, 1913), 151-155. Nicholl, "A study in the origins of Brunei," Brunei Museum Journal Vol. 7, No. 2 (1990): 24, fn. 38.

42 Huang, J., Huaqiao mingren gushilu 華僑名人故事錄 (Changsha: Shangwu yinshuguan, 1940), 2-3.

43 Lo, J-p., China as a sea power 1127-1368: A preliminary survey of the maritime expansion and naval exploits of the Chinese people during the southern song and Yuan periods, edited and with a commentary by Bruce A. Elleman (Singapore: NUS Press, 2012), 328 . Huang, Huaqiao mingren gushilu, 9-10.

Wade, G. "Po-luo and Borneo: A re-examination," Brunei Museum Journal Vol. 6, No. 2 (1986): 13-35.

46 Al-Sufri, J., Tarsilah Brunei, 15-16; Chen P. 陈平平, “Shiju xi Zheng He chuandui daoguo Boni de ruogan Mingdai shiliao yiju” 试举析郑和船队到过浡泥的若干明 代史料依据, Nanjing xiaozhuang xueyuan xuebao Vol. 4 (2009): 89-94; de Vienne, M-S., Brunei: From the age of commerce to the 21st century (Singapore: NUS Press, 2015), 42.

47 This text forms part of Geoff Wade's article, but was also discussed in a joint paper by Liu Yingsheng and Pg. Karim bin Pg Osman, "Two descriptions of Brunei in the Ming period" (n. d.), http://en.unesco.org/silkroad/sites/silkroad/files/knowledge-bankarticle/two_descriptions_of_brunei_in_the_ming_period.pdf, accessed August 8, 2017. It was thus available for perusal by writers lacking competence in classical Chinese. (1963): 51-52. (49-64).

Huang, Y., Ma Xing huaren zhi (Hong Kong: Mingjian chubanshe, 1967), 259-261. The book was republished in 2003 with a foreword by Zheng Liangshu 鄭良樹 and a biography of Huang Yao. Ibid, 261.

51 Hucker, Official titles, 246, entry 2592.

52 Ibid, 534, entry 7158.

53 Huang, Ma Xing huaren zhi, 260.

54 See Tuban, R., "A genealogy of the Sulu Sultanate," Philippine Studies Vol. 42, No. 1 (1994): 20-38.

55 See his "An analysis of the 'genealogy of Sulu," Asian Studies: Journal of Critical Perspectives on Asia Vol. 17 (1979): 1-17, and in Archipel Vol. 22 (1981): 167-182.

56 Majul, C. A., "Islam in the Philippines and its China link," Asian Studies: Journal of Critical Perspectives on Asia Vol. 35 (1999): 18-19, (12-27). In Najeeb M. Salleby's translations of the Sulu royal genealogies in his The history of Sulu (1908), no Chinese traders or merchants are mentioned.

57 Chen, L., Dongnanya huaqiao, huaren, huayi 東南亞華僑華人華裔 (Taibei: Zhengzhong shuju, 1979), 283.

58 Spenser St. John referred to this legend too, as well as to the Silsilah raja-raja Brunei. See his Life in the forests in the Far East, vol. 2 (London: Smith, Elder and Co., 1863), 832. 
59 It is very likely that this is the same person that Lee in 2013 addressed as Wang Qing Hong (see previous).

60 "It is known [...] that in A.D. 1413 the nine-year-old Maharaja Sura Wangsa returned from the Imperial Court to Brunei with his mother. They were not conveyed by Admiral Cheng Ho, therefore they might have been escorted by an Admiral Wong Soon Peng. Having delivered them safely to the capital, Admiral Wong might have sailed the length of the Borneo coast and up to Luzon, everywhere restoring Brunei authority, for it is noteworthy that no further tribute-bearing missions arrived from Luzon after A.D. 1410. The Admiral might have returned to Brunei, where he would have been greeted with acclaim for having restored the Empire. In recompense he might have been given a royal princess in marriage, and have settled down in Brunei to the enjoyment of some office.

Such could be the origin of the Ong Sum Ping legends, which figure prominently in Brunei folklore. His fame would have rested upon his having restored Brunei power, after it had been in abeyance for some sixty years. It is only a hypothesis, but it is a plausible one." See Nicholl, R., "Sources fort the early history of Brunei (typewritten MS, n. d.), entry 113. The Ming-shih: Admiral Cheng He and P'o-ni A.D. 1417."

${ }_{61}$ Harrison, T., "The advent of Islam to West and North Borneo: An attempted reconstruction of some possible sequences," JMBRAS Vol. 45, No. 1 (1972): 10-20. On page 15 Harrison writes: "the Admiral was both Moslem and Eunuch. It is plausible that during this period (? C. 1450 A.D.), one of his leading men came to Borneo. This would explain the famous Ong Sum Ping who figures prominently at the start of the Brunei chronicles as well as in much local folklore." The voyages of the Treasure Fleet were suspended in the early 1430s, so no "leading man" would have made it to Borneo in "1450 A.D.".

62 Chinese writers have assumed the tomb of Manarejiana in Nanjing to belong to a king of Brunei. See for instance Ji Shijia 季士家, “Zhongguo Wenlai youhao jiaowang de lishi jianzheng” 中國汶萊友好交往的歷史見證, Zijincheng Vol. 3 (1985): 42-44.

63 The website of the Huang family also strongly disputes the identification of Ong Sum Ping for the same reason. The editors of the website, as members of the Huang family of Guangdong, vigorously defend the idea of Huang Senping's arrival in "Brunei" (Wenlai) in 1375. See http://huang99.com/bk/show.asp?id=264 (accessed 4 November 2016).

64 Wang Jinghong is accorded historical rank equal to that of Zheng He in a publication from Fujian. See Zhu, M. 朱明元 et al. (eds), Wang Jinghong yu Zheng He xia xiyang 王景弘与郑和下西洋 (Hong Kong: Xianggang tianma tushu youxian gongsi, 2004). Roderich Ptak has reviewed this book. Remarking on two articles dealing with Ong Sum Ping by Yang Xinhua 杨新华 and Liu Xinsheng 刘新生, he suggested that it would be difficult to prove that the Treasure Fleet on any of its voyages stopped in Brunei. I have had no access to the original Chinese publication. For Ptak's review see Archipel Vol. 70 (2005): 312-317. Liu Xinsheng in the past served as the ambassador of the People's Republic of China to Brunei. Yang Xinhua has published an article concerning Wang Jinghong and Wang Sanpin to which I so far have had no access. See “Wang Jinghong yu Wenlai “Wang Sanpin””王景宏与文莱王三品, Zheng He yanjiu Vol. 1 (2005): 67-70. 


\section{Chinese sources" Verhandelingen van het Bataviaasch Genootschap van Kunsten en} Wetenschapen Vol. 39 (1880): 110-115.

67 Jamil Al-Sufri, Tarsilah, 41. Jamil Al-Sufri had picked up on the question first in 1990. See his Tarsilah Brunei: Sejarah awal dan perkembangan Islam (Bandar Seri Begawan: Jabatan Pusat Sejarah), 50.

68 There have been numerous attempts to transcribe the name. Groeneveldt addressed this chieftain as Maradja Ka-la. See Groeneveldt, Notes, 111; Pelliot rejected Groeneveldt's reading and suggested either Mahārāja Gyana-[nai] or Kara-[nai]. See Paul Pelliot, "Le Hoja et le Sayyid Husain de l'histoire des Ming," T'oung Pao Vol. 38, Livr. $2 / 5$ (1948): 268; Wang constructed Manara Kananai out of the original. See Wang, G., "China and Southeast Asia 1402-1424," in Studies in the social history of China and South-East Asia: Essays in memory of Victor Purcell, eds. Chen, J. and Tarling, N. (Cambridge: Cambridge University Press, 1970), 398.

69 Haji Ibrahim,A. L., "Theoretical linkages in the early history of Brunei," in Constructing a national past: National history and historiography in Brunei, Indonesia, Thailand, Singapore, the Philippines, and Vietnam, ed. Davies, P. (Bandar Seri Begawan: Universiti Brunei Darussalam, 1996), 154.

70 Song, L. 宋濂 (1310-81), “Boniguo rugong ji” 勃尼國入貢記 (Boni submits tribute), in Zhiyuan houji 芝園後集, 5.1399-5.1401. In Song Lian quanji 宋濂全集, in Song xue shi wenji 宋學十文集 vol. 3, ed. Luo, Y. 羅月霞 (Hangzhou: Zhejiang guji chubanshe, 1999). The most recent translation of this text into English is by Kurz, J. L., "Two early Ming texts on Borneo," Ming Studies Vol. 70 (2015): 60-72.

71 I am quoting from the text as it appears on http://huang99.com/bk/show.asp?id=264 (accessed 4 November 2016). I have not had access to the original work, Zhonghua xingshi tongshi: Huangshi 中华姓氏通史:黄氏 (Beijing: Dongfang chubanshe, 2000), 300-301, which apparently also is found in a text referred to as Huangshi tongshu 黄氏 通书 and edited by the Huangshi yanjiu hui 黄氏研究会. The website does not provide any further bibliographical information on this latter book.

72 Mingshi, 325.8415.

73 The queen was most likely Ratu Ijau (r. ?1584-1616). See Stefan Amirell, "The blessings and perils of female rule: New perspectives on the reigning queens of Patani, 1584-1716," JSEAS Vol. 42, No. 2 (2011): 303-323. Though it is quite clear that Dani is Patani, Wen Xiongfei had the famous pirate Lin Daoqian 林道乾 settle in Boni 勃泥. See Wen, Nanyang Huaqiao tongshi, 71. That is unlikely, since Patani local lore had Lin Daoqian marry Ratu Ijau in or around 1578. See Bradley, F. R., "Piracy, smuggling, and trade in the rise of Patani, 1490-1600," Journal of the Siam Society Vol. 96 (2009): 39-42.

74 See Tarsilah, 15.

75 Ibid. Jamil refers to "Roll 325, Episode 213" in the Mingshi. Roll certainly stands for chapter or juan which is the correct one for the Boni entry, but "episode" remains a mystery.

76 See for instance Yunos, R., "The golden legacy: Ong Sum Ping," http://www.bt.com. bn/golden-legacy/2010/12/27/golden-legacy-ong-sum-ping (accessed 23 May 2016). 
Rozan describes Ong Sum Ping as a "great Chinese voyager on the west coast of Sabah" and as a "Chinese Moslem."

Sultanate and its relationship with other countries," in Brunei: History, Islam, society and contemporary issues, ed. Ooi, K. G. (Routledge, 2015), 51, (45-61). Ampuan Haji Brahim gives a good introduction to the often-confusing relations in the early history of the Brunei sultans that local writers established by reading disconnected texts in conjunction instead of treating them as separate histories.

81 Cited in Ampuan Haji Brahim, "Silsilah," 52. The original article by Jamil Al-Sufri with the title "Sultan Sharif Ali" was published in Jurnal Darussalam Vol. 1 (1992): 6. In a later article Jamil had "Ong Sum Peng" convert to Islam, apparently because he married the daughter of the first sultan. As a consequence of his familial ties he stayed in Brunei and adopted the title Pengiran Maharaja Lela. See "Raja Brunei berasal dari China?" Jurnal Darussalam Vol. 6 (2006): 10 (6-11). This article served to disprove suggestions that the early rulers of Brunei originated from China.

82 The most recent proponent of this idea is Ampuan Haji Brahim: "The party was led by Chang Ching Tze and Sin Tze. They recounted that the king of Brunei was 'Mahamosha,' a Chinese rendition of Muhammad Shah." See Ampuan Haji Brahim bin Ampuan Haji Tengah, "Silsilah," 50. Note that the names of the two emissaries are transcribed as Cantonese when their names in standard Chinese read Zhang Jingzhi 張敬之 and Shen Zhi 沈秩.

83 See Yuanshi, 106.2697-106.2699.

84 See the relevant chapter in Mingshi 113.3505-113.3509.

"... and the said king of China confirmed in him the title of king and gave him the insignia and royal [coat of arms] which nowadays the said king of Borney has; and seeing that the said Sultan Yuso was a bachelor, he married him to a Chinese woman. Accordingly it appears that the reason he persevered in the said kingdom [of Borney] was that she was a relative of the king of China." See Carroll, J. S., "Brunei in the 'Boxer Codex," JMBRAS Vol. 55, No. 2 (1982): 4.

88 I would like to thank John N. Crossley for kindly sharing his knowledge on the Boxer Codex with me, including references to another translation of the text into modern Spanish, and his article "The early history of the Boxer Codex," JMBRAS Vol. 24, No. 1 (2014): 115-124. The new Spanish translation by Isaac Donoso is found here: http://revista.carayanpress.com/styled-31/styled-42/index.html, and here: http://revista. carayanpress.com/styled-3/styled-29/filipinas-aullon.html, both accessed August 27, 2017. I have had no access to Boxer Codex: A modern Spanish transcription and English translation of early exploration accounts of ancient East and Southeast Asia, transcribed and annotated by Isaac J. Donoso; translated by Ma. Luisa Garcia, Carlos Quirino and Mauro Garcia (Manila: Academia Filipina, 2016); nor to Jeffrey 
S. Turley and George Bryan Souza, The Boxer Codex: Transcription and translation of an illustrated late sixteenth-century Spanish manuscript concerning the geography, history and ethnography of the Pacific, South-east and East Asia (Leiden: Brill, 2015). 陈平平, "Mingchu Boni guowang de chaogong lipin jiqi shengwu fenleixue yanjiu" 明初浡泥国王的朝贡礼品及其生物分类学研究, Nanjing xiaozhuang xueyuan xuebao Vol. 4 (2008): 44-50.

91 For an alternative view that places Boni in Vietnam, see Charignon, A. J. H., "La grande Java de Marco Polo en Cochinchine: Etude de géographie historique d'après les sources chinoises et arabes," Bulletin de la Société des Etudes Indochinoises Vol. 4, No. 4 (1929): 322-330.

92 Since 2006 (the year the website was created) Abdul Majid Hasan has been ranked as the second sultan of Brunei in a list of Brunei rulers published by the Brunei History Centre. See http://www.pusat-sejarah.gov.bn/Themed/sultanbrunei.htm (accessed 20 August 2017). It may be a coincidence only that in the same year the China-Brunei Friendship Park was officially opened on the site of the mausoleum of the Boni chieftain south of Nanjing.

93 P. M. Sharifuddin and Abdul Latif bin Hj. Ibrahim discuss the dating of the tablet in their "The genealogical tablet (Batu Tarsilah) of the Sultans of Brunei," Brunei Museum Journal Vol. 3, No. 2 (1974): 253-264.

94 Nicholl, R., "Notes on some controversial issues in Brunei history," Archipel Vol. 19 (1980): 35 .

95 Brunei: The structure and history, 186.

96 According to Y. L. Lee the Chinese population in north Borneo only in the 19th and 20th centuries increased significantly. See "Historical aspects of settlement in British Borneo," Pacific Viewpoint Vol. 2, No. 2 (1961): 190. 